\title{
Cluster-based pre-scaling up of improved faba bean variety technology demonstration at Arsirobe District of Arsi
} \section{Zone, Oromia Regional State,} Ethiopia

\author{
Sintayehu Abebe ${ }^{1 *}$ and Lemlem Abebe $^{2}$ \\ 'Ethiopian Institute of Agricultural Research, Kulumsa Agricultural Research Center, Assela, P. \\ O.Box489, Ethiopia
}

${ }^{2}$ Ethiopian Institute of Agricultural Research, Addis Ababa .P.O.BOX; 2003 Addis Ababa, Ethiopia

Received: 20 July, 2021

Accepted: 30 August, 2021

Published: 31 August, 2021

*Corresponding author: Sintayehu Abebe, Ethiopian Institute of Agricultural Research, Addis Ababa .P.O.BOX: 2003 Addis Ababa, Ethiopia,

E-mail: sintu454@gmail.com

Keywords: Demonstration; Faba bean; Large scale; pulse

https://www.peertechzpublications.com

Check for updates

\begin{abstract}
Large Scale Demonstration (LSD) of Faba bean was conducted at Arsi robe district of Oromia regional state of Ethiopia. The district was selected due to its potential for Faba bean production. One cluster was formed in collaboration with district level agricultural experts.Generally the cluster size covered 4.6 hectares of land. A Faba bean varity called "Ashebeka" was demonstrated along with its full-recommended packages. Training were given for a total of 46 participants (39 farmers, 3 DAs and 4 SMS) at different stage on agronomice practice of Faba bean and chemical applications. To raise farmer's awareness on the performance of the Faba bean techinologies, a field day was organized and by this field day, a total of 74 participants were attended the field events ( 59 farmeres, 7 Experts and DAs and 5 distinguished guests were attened the events). From the varity demonstrated at study district the variety was acceptable during field visit and field day by farmers due to its disease tolerant and well adaptation and its productivity after harvesting (the varity has a yield advantage overe the Ethiopial national average yield of fababean (21quintals per hectare CSA 2020 and "Ashebeka"; Avarage Yield=30.2; quintals per hectare was recorded in the study area.
\end{abstract}

\section{Background and justification}

Faba bean (Vicia faba L.) is believed to be one of the earliest domesticated legumes next to chickpea and pea $[1,2]$.

It is an important pulse crop produced all over the world for both foods, feed \& it serves as a cheap source of protein. It also plays a great as an excellent crop for fixing atmospheric nitrogen $[3,4]$.

In Ethiopia, faba bean is grown in the highlands (18003000 m.a.s.l.). Both Amhara and Oromiya are the two major pulse-producing regions in Ethiopia [5]. Among the twelve pulse species grown in Ethiopia. Faba bean (Vicia faba L.) is one of pulse crops grown in the cooler highlands [6].
Next to China ,Ethiopia is the second largest faba bean producing country in the world. The crop occupies close to $466,697.68$ hectares of land with an annual production close to $10,067,518.28$ quintals [7]. Even though Ethiopia is the world's second largest producer of faba bean, its share is not exceed $7 \%$ of world production [8].

The major factors that are usually mentioned for the low yield of faba bean in Ethiopia include climatic, edaphic, biotic (diseases, pests and weeds) factors, and poor agronomic practices [9].

Majority of the farmers use low yielding of the local varieties which contribute for low production $[10,11]$. 
When comparing the yield of fababean in Ethiopia :it is below the world average due to several factors: among these lack of improved seed is a key [12]. Therefore, this activity was aimed at promoting high yielding and most adaptable faba bean varity called "Ashebeka" in the study area by a new extension modality i.e Large Scale Demonstration (LSD) or cluster-based farming with following general and specific objectives.

\section{Objective}

General objective: Generally, this activity was aim to contribute for Food security by promoting newly released Faba bean technologies through Large Scale Demonstration (LSD).

\section{Specific objectives are:}

1. To access and utilization of improved Faba bean technologies

2. To aquainte the Large Scale Demonstration (LSD) approach for the concerned body and to understand the benefits of LSD approach

3. To create awareness on the importance of Faba bean technologies among stakeholders,

4. To document best practices, experiences, and lessons learned from the large-scale demonstration of Faba bean varieties.

\section{Materials and methods}

\section{Description of the study areas}

The activity was implemented in Arsirobe district of potential among Faba bean producing districts of Oromia regional state in 2019/20 cropping season.

Arsi robe district: Arsi robe district is situated at a distance of about $225 \mathrm{~km}$ from Addis Ababa and $98 \mathrm{~km}$ from the Eastern Arsi zone capital city, Asela. The district is situated in Eastern Arsi Zone, Oromia regional state of geographical locations. The district has a bimodal rainfall pattern consisting of along rainy season "kiremit" from July to September and short rainy season "belig" extending March to May. It has an Latitude (DMS) of $09^{\circ} 36^{\prime} \mathrm{N}$ and Longitude (DMS) $39^{\circ} 08^{\prime} \mathrm{E}$. [13,14]. Barley, fababean, Bread wheat from cereals and Oil seeds, specifically flax, nueg and rape seed, are important cash crops grown in the district [14].

\section{Input utilization}

A Faba bean Variety called "Ahebeka"was demonstrated along with its full-recommended packages. Planting was also done in a row at a seed rate of $200 \mathrm{~kg} \mathrm{ha}^{-1}$, NPS fertilizer were applied at the rate of $121 \mathrm{~kg} \mathrm{ha}^{-1}$. Ploughing, weeding, and other agronomic management practices were applied by farmers according to the recommendations.

\section{Method of data collection}

Data on Yield was collected and comparison with Ethiopian national average yield was made among the varieties planted in the study area (Cluster).

\section{Data analysis method}

The collected data (quantitative data) was analyzed by using average grain yield and package comparison among study areas were made.

\section{Locations and farmers selection}

The activity was implemented in Arsirobe one of potential of Faba bean producing districts of Oromia regional state in 2019/20 cropping season. Arsi robe was from Arsi zone Oromiya regional state. Was selected for Large Scale Demonstration (LSD) program.

\section{Direct and indirect beneficeries of farmers}

In general, 16 farmers (16 Male) were got an improved variety of Faba bean called "Ashebeka" according to the land allocated for the demonstration program, so that they were directly benefited in the activity and 16 farmers (Male) were benefited directly from input (improved seed) and 46 farmers (28 Male and 18 Female) were benefited from the training provided on different training topics sponsored by byEthiopian Institute of Agricultural Research (EIAR) and facilitated by kulumsa Agricultural Research Center (KARC) and 72 participants (53 Male and 19 Female) were also participated/benefited in the field days and in experience shring events directly.

Faba bean: As indicated in Table 1: One district was namely Arsirobe from Arsi zone, among fababean growing districts was selected for Faba bean techinologies demonstration in Large Scale Demonstration (LSD) program.

A Faba bean cluster which contains 4.6 hectares of land was formed in collaboration with the district level experts and "kebeles" level Development Agents (DAs).

Faba bean varity demonstrated and popularized: Regarding the varity demonstrated and promoted in large scale demonstration. In large scale demonstration on one cluster which covered 4.6 hectares of land in Arsi zone which was coordinated and facilitated by Kulumsa Agricultural Research center.

\section{Trainings provided on faba bean techinologies for the beneficerice farmers as well as other stakeholders}

As indicated in Table 2: In general Training were given for 46 participants for different stakeholders on agronomice practice of Faba bean, chemical applications and safety mechanisms.

Again as indicated in Table 2, a total of 39 farmers (23 male and 16 female) were attende on different topics of training. Regarding developing agents (DAs) an awerness creations were made on the Faba bean related issues by this a total of 3 DAs (2 Male and 1female) were attended. Different experts also gain different training on fababean techinologies in this regards a total of 4 experts ( 3 male and 1 female experts at district level were attended training on Faba bean techinologies related.

Citation: Abebe S, Abebe L (2021) Cluster-based pre-scaling up of improved faba bean variety technology demonstration at Arsirobe District of Arsi Zone, Oromia Regional State, Ethiopia. Open J Plant Sci 6(1): 087-090. DOI: https://dx.doi.org/10.17352/ojps.000038 


\section{Field days}

To raise farmer's awareness on the performance of the Faba bean techinologies, field day was organized ,by this field day, a total of 74 participants were attend the field events. Among these 59 participants were farmers ( 43 Male and 16 Female),4 participants were Development Agents (DAs) (3male and 1 female) again 4 of participants were also experts (3 Male and 1 Female), 5 participants were others invited special guests (4 Male and 1 Female) were attended the field days and belived that awareness were created among participants of the field days including experts, SMS, DAs and among participant farmers (Table 3 below).

\section{Faba bean productivity at study area}

* Status of "Ashebeka" varity popularized in LSD in 2019/20 cropping season

As indicated in Table 4 below an actual grain yield of the variety Ashebeka was collected from 4.6 hectares of land from Arsi robe district of Arsi zone of Oromia regional state and a minimum of 18.7 quintals per hectare, a maximum grain yields of 42.1 quintals per hectare and an average grain yields 30.2 quintals per hectare per cluster were scored.

\section{Summery, conclusion and recommendations}

Ethiopia is one of the major faba bean growing countries in the world but with a low average national yield $(\leq 2 \mathrm{t}$ ha-1)

Table 1: Indicate area Covered by Large Scale Demonstration ( LSD ) on Faba bean techinologies.

\begin{tabular}{|c|c|c|c|c|c|c|c|}
\multirow{2}{*}{ Region } & \multirow{2}{*}{ Zone } & \multirow{2}{*}{ District } & \multicolumn{2}{|c|}{ No.Farmers } & \multirow{2}{*}{ Varities } & \multirow{2}{*}{ No.clusters } & \multirow{2}{*}{ hectars } \\
\cline { 3 - 6 } & & & $\mathrm{M}$ & $\mathrm{F}$ & & 1 & 4.6 \\
\hline Oromia & Arsi & Arsi robe & 16 & 0 & Ashebeka & 1 & 1 \\
\hline Total & 1 & 1 & 16 & 0 & 1 & 1 & 4.6 \\
\hline
\end{tabular}

Table 2: Trainings given by the research center(KARC) to beneficeries.

\begin{tabular}{|c|c|c|c|}
\hline \multirow{2}{*}{ S.No } & Participants & \multicolumn{2}{|c|}{ Gender } \\
\cline { 3 - 4 } & Farmers & M & F \\
\hline 1 & Development Agents (DAs) & 23 & 16 \\
\hline 2 & Experts & 3 & 1 \\
\hline 3 & & 28 & 18 \\
\hline Total & & & \\
\hline
\end{tabular}

Table 3: Number of participants for the field day events.

\begin{tabular}{|c|c|c|c|}
\hline S.No & Participants & \multicolumn{3}{|c|}{ Gender } \\
\hline & & M & F \\
\hline 1 & Farmers & 43 & 16 \\
\hline 2 & Development Agents (DAs) & 3 & 1 \\
\hline 3 & Experts & 3 & 1 \\
\hline 4 & Other invited guest & 4 & 1 \\
\hline Total & & 53 & 19 \\
\hline
\end{tabular}

Table 4: Shows minimum, Maximum and average yield per hectare.

\begin{tabular}{|c|c|c|c|c|c|c|c|}
\hline Varitiy & Zones & district & cluster & Hectares & Min. & Max & Ava. \\
\hline Ashebeka & Arsi & Arsi robe & 1 & 4.6 & 18.7 & 42.1 & 30.2 \\
\hline 1 & 1 & 1 & 1 & 4.6 & & & \\
\hline
\end{tabular}

compared to yield levels in other countries [9]. The objective of this study was to demonstrated high yielder fababean varity colled "Ashebeka" along with its full-recommended packages.

The activity was implemented in oromia of Ethiopia in 2019/20 croping season. Arsirobe from Arsi zone Oromia regional state was selected for Faba bean techinologies demonstration in Large Scale Demonstration (LSD) program due to the area has a potential for fababean.

The actual yields of varity of fababbean was collected and analised per cluster and there was a promising average yield was recorded the varity "Ashebeka" in the study area showed higer yield than the average Ethiopian national average fababean yield 21 quintals per hectare [7].

To raise awerness among stakholders traings were prepared by these traings a total of 39 farmers ( 23 male and 16 female) were attende on fababean techinologies. Regarding developing agents (DAs) an awerness creations was made on the Faba bean related issues by this a total of 3 DAs ( 2 Male and 1 female) were attended. Different experts also gain different training on fababean techinologies in this regards a total of 4 experts (3 male and 1 female experts at district level were attended.

To raise farmer's awareness on the performance of the Faba bean techinologies, field day was organized,by this field day a total of 72 participants were attend the field events. Among these 59 participants were farmers ( 43 Male and 16 Female), 8 of participants were experts and DAs (6 Male and 2 Female), 5 participants were others invited special guests ( 4 Male and 1 Female) were attended the field days and belived that awareness were created among participants of the field days including zonal experts, SMS, DAs and among participant farmers.

As conclusion: During the implementation year of the the activity based on the data collected and from recerchers observation points of view concluded that the following points were addressed.

1. Access and utilization of improved Faba bean technologies were enhanced

2. The Large Scale Demonstration (LSD) approach was well aquainted and understood among stakeholders

3. Awareness on the importance of Faba bean technologies were created among stakeholders.

\section{Recommendations}

In general cluster based approach with new verity and input utilization demonstration was successful in terms of yield. Therefore, based on this result the researcher recommend farmers and other development practitioner to focus more on Large Scale Demonstration (LSD). Again the author recommend the farmers to produce in cluster farming approach for scale up activity with best performed Faba bean varity has to be done in areas where Faba bean is not scaled up especially in areas where Faba bean is potential like study area. 
Faba bean is potential crop in the highlands of Ethiopia in general. The crop is primarily used for household consumption and generating income for farmers and improve soil fertility. The average yields of the varity "Ashebeka" demonstrated has yield advantage over the Ethiopian national Faba bean average 21 quintals per hectare [15]. Therefore, implementing LSD approach can improve yield, so it should be better for farmers and development practioners to use it as a good extension approach.

Now a days commercialization is an agenda for the goverments of Ethiopia so the cluster-based (Large Scale Demonstration) approach is a good start to met the commercialization issue. Therefore, concerned body should exercise the Large Scale Demonstration (LSD )as one extension modality.

\section{Acknowledgements}

The Authors would like to acknowledge EIAR (Ethiopian Agricultural Research Institute) for its financial support. Farmers and development agents directly involved for the completion of pre scaling up improved fababean research activity also heartily acknowledged. During clustering and at different follow up stage and field days Arsirobe district office expert also contribute a lot and for this the authors also acknowledge them for their commitment.

\section{References}

1. Hailu E, Getaneh G, Sefera T, Tadesse N, Bitew B, et al. (2014) Anteneh Boydom,Daniel Kassa and Tamene, Faba Bean Gall; a New Threat for Faba Bean (Vicia faba) Production in Ethiopia. Advances in Crop Science and Technology 2: 5. Link: https://bit.ly/3kEhXU4

2. Tadele M, mohammed W, Jarso M (2019) Genetic Variability on Grain Yield and Related Agronomic Traits of Faba Bean (Vicia faba L.) Genotypes Under Soil Acidity Stress in the Central Highlands of Ethiopia. Chemical and Biomolecular Engineering 4: 52-58.

3. Abera T, Debele T, Semu E, Wegary D, Kim H (2016) Faba bean precursor crop and $\mathrm{N}$ rates on subsequent yield components of maize in Toke Kutaye, western Ethiopia. Sky Journal of Agricultural Research 5: 001 - 014. Link: https://bit.ly/2WAKuC4

4. Eshetu G, Bimrew Y, Shifa H (2018) Association of Chocolate Spot and Faba Bean Rust Epidemics with Climate Change Resilient Cultural Practices in Bale Highlands, Ethiopia. Hindawi 6042495. Link: https://bit.ly/2WEAuHO

5. Yitayih G, Azmeraw Y (2017) Adaptation of faba bean varieties for yield for yield components and against faba bean gall (Olpidium viciae Kusano) disease in South Gondar, Ethiopia. Crop Science Society of China (CSSC) 560 566. Link: https://bit.ly/2Y9Vozd

6. IFPRI (2010) Pulses Value Chain in Ethiopia.

7. CSA (2020) Area and Production of Major Crops. CSA: ADDIS ABABA 137.

8. Mitiku M (2017) Integrated Management of Chocolate Spot (Botrytis Fabae) Disease Of Faba Beans (Vicia Faba L.) In Ethiopia: A Review. International Journal of Research - Granthaalayah 5: 195-205. Link: https://bit.ly/3ysmuOr

9. Mulugeta W, Tesfaye K, Getnet M, Ahmed S, Nebiyu A, et al. (2019) Quantifying Yield Potential and Yield Gaps of Faba Bean in Ethiopia. Ethiop. J Agric Sci 29: 105-120. Link: https://bit.ly/3kCHc9u

10. Wolday K (2018) Evaluations of faba bean (Vicia faba L.) varieties for yield and yield related traits in central zone of Tigray,Northern Ethiopia. Journal of Plant Breeding and Crop Science 10: 258-261. Link: https://bit.ly/3kAbhGL

11. Negasa G (2019) Influence of Phosphorus Fertilizer Rates on Yield and Yield Components of Faba Bean (Vicia faba L.) Varieties in Lemu Bilbilo District of Arsi Zone, Southeastern Ethiopia. International Journal of Plant \& Soil Science 28: 1-11. Link: https://bit.ly/3zuZfVI

12. Dobocha D, Worku W, Bekela D, Mulatu Z, Shimeles F, et al. (2019) The response of Faba bean (Vicia faba L.) varieties as evaluated by varied plant popu- lation densities in the highlands of Arsi Zone, Southeastern Ethiopia. Researchs / Investigación 4: 6. Link: https://bit.ly/3BkZOkY

13. Mengistu W (2014) Socio-Economic Challenges of Smallholder Farmers in Agricultural Practice in Robe Woreda, Arsi Zone, Oromia Region. School of Graduate Studies College of Social Sciences, Addis Ababa, Ethiopia 93. Link: https://bit.ly/3ky3A3S

14. Wikipedia (2020) Robe (woreda), in Robe (woreda).

15. CSA (2020) Area and Production of Major Crops. The Federal Democratic Republic of Ethiopia Central Statistical Agency, CSA ADDIS ABABA

\section{Discover a bigger Impact and Visibility of your article publication with}

Peertechz Publications

\section{Highlights}

* Signatory publisher of ORCID

* Signatory Publisher of DORA (San Francisco Declaration on Research Assessment)

* Articles archived in worlds' renowned service providers such as Portico, CNKI, AGRIS, TDNet, Base (Bielefeld University Library), CrossRef, Scilit, J-Gate etc.

* Journals indexed in ICMJE, SHERPA/ROMEO, Google Scholar etc.

* OAI-PMH (Open Archives Initiative Protocol for Metadata Harvesting)

* Dedicated Editorial Board for every journal

* Accurate and rapid peer-review process

* Increased citations of published articles through promotions

* Reduced timeline for article publication

Submit your articles and experience a new surge in publication services (https://www.peertechz.com/submission).

Peertechz journals wishes everlasting success in your every endeavours.

Copyright: @ 2021 Abebe S, et al. This is an open-access article distributed under the terms of the Creative Commons Attribution License, which permits unrestricted use distribution, and reproduction in any medium, provided the original author and source are credited. 